\title{
Literasi Digital Bagi Keluarga Milenial Dalam Mendidik Anak Di Era Digital
}

\author{
Rini Indriani ${ }^{1}$, M. Yemmardotillah ${ }^{2}$
}

${ }^{1}$ MAN 3 Padang Panjang, Indonesia

2 STIT Ahlussunnah Bukittinggi, Indonesia

Corresponding Author: @ indrie.mdn@gmail.com

ARTICLE INFO
Article history:
Received
01 July 2021
Revised
10 July 2021
Accepted
20 July 2021

Keywords

How to cite

\section{ABSTRACT}

The development of technological advances in the digital era brings very significant changes in all aspects of life. In this digital era, educational problems become very diverse with the increasing family responsibilities. To deal with these developments, the expertise of parents and educators is needed to implement the right solutions to all these problems and also the ability to adapt to environmental changes. This study examines in depth digital literacy for millennial families in educating children in the digital era. Digital literacy skills are needed by teachers and parents in educating children so that they can play various roles as educators in this digital era. This research uses library research method. Data collection in this study was carried out by elaborating various kinds of literature in the form of books, journals, e-books and literature relevant to digital literacy problems in millennial families in the digital era. The data analysis technique uses content analysis methods from journals and other documents that are accessed via the internet. The results show that in this digital era the role of parents is needed so as not to be left behind. In this era, there is a need for a new reorientation of learning because it is considered to affect vision, responsibility, social sensitivity and logical ability, as well as honesty. All of this leads to a reorientation of the new role of parents, namely as agents of change, knowledge renewal, and learning consultants that emphasize creativity, initiative, good communication and cooperation between parents, schools and communities.

Digitaly Literacy, Millenial Families, Children Education

Rini Indriani $^{1}$, M. Yemmardotillah² ${ }^{2}$ (2021). Literasi Digital Bagi Keluarga

Milenial Dalam Mendidik Anak Di Era Digital. Journal Continuous Education, 2(2). 1-13. 10.51178/ce.v2i2.223

\section{PENDAHULUAN}

Perkembangan ilmu pengetahuan dan teknologi pada saat sekarang ini telah membuat dunia seakan tanpa batas, berbagai macam aktivitas komunikasi secara maya ke seluruh penjuru dunia dalam waktu singkat serta majunya teknologi dan komunikasi memicu berbagai perubahan kehidupan manusia. Kemajuan tersebut memunculkan inovasi baru yang berpengaruh pada beberapa sektor, seperti ekonomi, budaya, dan sosial. Teknologi telah menggeser fungsi manusia dan mengubah cara kerja, bekerja, belajar dan lain sebagainya. (Tritularsih, 2017). Hal ini mengakibatkan berubahnya cara manusia berpikir, hidup, dan berhubungan satu dengan yang lain, termasuk tren bekerja dari rumah (WFH) karena perkembangan teknologi yang semakin canggih dan adanya penyebaran pandemi global virus Covid- 
19 yang membuat masyarakat melakukan kegiatan atau pekerjaan di rumah saja (Setyawati, 2020). Semua harus dapat membiasakan diri dengan belajar dan bekerja dirumah, segala macam bentuk aktivitas yang dikerjakan hanya dirumah saja, tidak hanya itu rutinitas belajar mengajar di sekolah pun beralih ke peran orangtua di rumah (Umar,2015), sehingga penggunaan internet dalam kehidupan keluarga akan meningkat. Seluruh anggota keluarga akan sering menggunakan media digital dalam bermacam bentuk, diantaranya komputer atau laptop, game online dan internet. Penggunaan media digital di dalam keluarga tidak semuanya dapat meningkatkan kualitas kehidupan berkeluarga. Ada keluarga yang mengalami broken home karena lebih banyak menghabiskan waktu dengan media digital. (Wicaksono, dkk.2019).

Seiring dengan kemajuan tersebut, masyarakat sebagai sasaran utama dalam penyediaan informasi, tentu sangat diuntungkan dengan perkembangan teknologi komunikasi masa kini. Tapi di lain sisi, perusahaan-perusahaan yang berbasis media sangat gencar menyiarkan informasi, Namun, tidak diimbangi dengan edukasi dalam mengolah informasi. (Winerda, 2019). Artinya Kemampuan literasi media yang baik akan berdampak baik terhadap informasi yang diperoleh dan sebaliknya.

Orang tua sebagai lingkungan pertama dan utama bagi anak memegang peranan paling penting dalam mendidik anak. Orangtua tidak dapat menutup mata dan menghindari era digital, karena saat ini digitalisasi sudah merambah di semua bidang, maka orang tua harus memberikan bimbingan dan arahan terhadap anak dalam menggunakan media digital dengan bijaksana. Maka orang tua perlu memahami nilai utama dunia digital yang dapat mempengaruhi kehidupan manusia saat ini. Setidaknya ada tiga nilai penting yang berpengaruh yaitu kreatiftas, kolaborasi dan berpikir kritis. (Kurnia, 2017).

Anak merupakan amanah yang diberikan oleh Allah SWT yang tidak ternilai harganya yang harus disyukuri, dijaga dan dipelihara dengan baik oleh orang tua. Salah satu caranya adalah melalui pendidikan dan pengajaran. Dalam menuju proses kedewasaannya anak memerlukan berbagai proses yang diperankan oleh orang tua mereka. Pengalaman yang di dapat oleh anak anak akan mempengaruhi kematangan anak. Kesadaran orang tua akan peran dan tanggung jawabnya sebagai pendidik dalam keluarga sangat diperlukan, karena hal ini akan berpengaruh terhadap pertumbuhan dan perkembangan serta kematangan anak. Hal ini dijelaskan oleh Rasulullah SAW dalam sabdanya yaitu: "setiap anak yang dilahirkan dalam keadaan fitrah, maka kedua orang tuanyalah yang menjadikan ia Yahudi, Nashrani ataupun Majusi" (HR. Bukhari).

Orang tua bertanggungjawab dalam memenuhi kebutuhan anak, membimbing, mendidik dan memberikan contoh teladan. Tanggungjawab tersebut diantaranya adalah tanggung jawab keimanan, materi, fisik, moral, akal, kejiwaan, sosial, dan seks. Tanggung jawab ini dijelaskan Allah SWT dalam surat at-Tahrim ayat 6 sebagai berikut: 


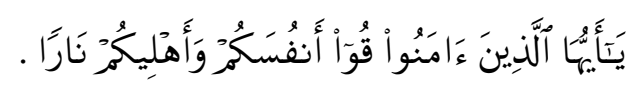

Artinya : Hai orang-orang yang beriman, peliharalah dirimu dan keluargamu dari api neraka yang bahan bakarnya adalah manusia dan batu. ( Departemen Agama, 2009).

Penjelasan ayat tersebut dapat dipahami bahwa sudah menjadi suatu kewajiban orang tua mendidik anaknya sebelum pendidikan anak diserahkan kepada orang lain, seperti lembaga pendidikan. Orang berperanan penting dalam pendidikan anaknya. Tanggung jawab tersebut diaplikasikan dalam bentuk pendidikan, dimana tujuannya adalah untuk meciptakan anak-anak menjadi manusia yang sehat, cerdas, berkarakter mulia, berakhlak serta mampu menjadi generasi kuat dan memiliki masa depan yang cerah. Agar hal itu tercapai dengann baik, maka orang tua di samping harus mengetahui dan memahami, orang juga harus menerapkan pendidikan tersebut sesuai dengan tahapan-tahapan perkembangan anak yang berlandaskan syariat Islam seperti yang dicontohkan oleh Rasulullah SAW dalam sunnahnya. Oleh karena itu sangat urgen bagi orang tua memberikan prilaku, pendidikan dan pengajaran yang baik ke anak, agar disaat dewasa anak tersebut dapat mengetahui mana yang baik dan mana yang buruk serta mampu menjaga dirinya dan keluarganya.

Dalam proses pendidikan khususnya pendidikan Islam sangat banyak mengajarkan kepada orang tua betapa pentingnya menjadi figur atau contoh teladan dalam keluarga yang dapat membentuk kepribadian anak agar lebih baik, sehingga anak tumbuh dab berkembangan menjadi anak yang baik. Keluarga milenial muslim harus mampu menjalani keluarga yang berpedoman kepada al-Qur'an dan sunnah, serta literatur-literatur lain yang secara spesifik yang membahas tentang tata cara mendidik anak dalam Islam, yang sangat berkaitan dengan keberhasilan orang tua dalam hal pertumbuhan dan perkembangan anak agar menjadi pribadi yang ideal, sehingga akan tercipta anak-anak yang mempunyai kondisi fisik yang sehat, mempunyai kepribadian yang baik, matang dalam emosi, sehat mental, kreatif, psikologis yang sehat dan berimplikasi positif terhadap lingkangan sekitar dan tempat tinggalnya.

Proses pendidikan yang baik harus dapat memenuhi kebutuhan dalam literasi manusia, menjadi penting untuk bertahan di era revolusi industri ini, agar manusia bisa berfungsi dengan baik di lingkungan manusia dan mampu interaksi dengan baik terhadap sesama manusia dalam era yang begitu cepat dalam perkembangan revolusi industri. Kondisi perkembangan zaman yang semakin canggih serta serba modern, diperlukan orang tua untuk lebih ekstra hati-hati dalam menjaga, membimbing, dan memperhatikan tumbuh kembang anak, supaya tidak terjerumus ke dalam dampak negatif dari perkembangan zaman. Orang tua harus jeli melihat dan mengikuti perkembangan teknologi agar dapat membimbing dan mengarahkan anaknya. Untuk itu orang tua hendaknya memiliki wawasan yang luas dalam mendidik anak secara Islami yang dapat diterapkan dalam keluarga.

Merujuk dari permasalahan di atas, maka dipandang perlu untuk dilakukan penelitian yang mendalam dan konprehensif tentang literasi digital bagi keluarga 
milenial dalam mendidik anak di era digital. Penelitian ini bertujuan untuk mengekplorasi pentinya literasi digital bagi keluarga milenial dalam mendidik anak di era digital.

\section{METODE PENELITIAN}

Penelitian ini menggunakan metode kepustakaan atau dikenal dengan (library research). Teknik pengumpulan data dalam penelitian ini adalah dengan mengelaborasi berbagai macam literature baik berupa buku, jurnal, e-book maupun literature yang relevan dengan masalah-masalah literasi digital dalam keluarga milenial di era digital. Teknik analisis data menggunakan metode analisis isi (Content Analysis) jurnal-jurnal dan dokumen lain yang di akses melalui intenet (Sari, 2020). Metode kepustakaan ini dipilih karena penulis ingin mengkolaborasikan temuan-temuan penelitian yang senada sebagai kajian penelitian yang relevan dalam konteks kekinian (Zed, 2008), sehingga dapat menemukan sesuatu yang baru (novelty) dalam penelitian selanjutnya.

\section{HASIL PENELITIAN DAN PEMBAHASAN}

\section{Hakikat dan Peran Orang Tua dalam Keluarga Milenial di Era Digital}

Lingkungan keluarga adalah lingkungan pendiidkan yang pertama dan utama bagi seorang anak karena di dalam keluarga anak pertama kali mendapatkkaan didikan dan bimbingan dan juga sebagian besar kehidupan anak berada dalam keluarga. Keluarga yang secara kodrati beranggungjawab memelihara, merawat, melindungi, dan mendidik anak agar tumbuh dan berkembang dengan baik (Hasbullah, 2003). Berbicara tentang konsep keluarga tidak bisa lepas dari konsepnya yang terus berubah seiring dengan perkembangan zaman. Walaupun mengalami perubahan, sebuah keluarga tetap banyak fungsi seperti fungsi pendidikan, fungsi sosialisasi, reproduksi, ekonomi namun aplikasinya berkemungkinan bisa berubah sesuai dengan tuntutan hidup. Zaman dahulu keluarga identik dengan peranan ayah sebagai pencari nafkah untuk keluarga dan ibu berada di rumah mengurus rumah beserta anak-anak, maka zaman sekarang terjadi perubahan, ayah tetap mencari nafkah dan ibu pun juga ikut mencari nafkah. Maka, dalam konteks kekinian keluarga milenial adalah keluarga yang terdiri dari para pasangan muda yang lahir berkisar pada tahun 1981-1994 atau disebut juga dengan milenial. (Rahmawati, 2019).

Dalam sebuah keluarga orang tua adalah pendidik yang pertama dan utama. orang tua memiliki peran masing-masing dalam menjalani perannya sebagai pendidik dalam kelurganya. Sebagai kepala keluarga, seorang ayah harus dapat mempersiapkan anggota keluarganya dari segala sesuatu yang dibutuhkan, dimana bimbingan, ajakan, pemberian contoh, kadang sanksi dan hukuman, adalah sifat pendidikan terhadap anak yang khas dalam sebuah keluarga, seperti pekerjaan rumah, dan masyarakat yang dilakukan oleh seluruh anggota keluarga, atau secara mandiri, merupakan suatu cara yang sudah biasa terjadi dalam interaksi pendidikan dalam keluarga. Dalam hal ini, (Zakiah, 1973) menyatakan, bahwa cara ayah dalam melakukan pekerjaan sehari-hari mempunyai pengaruh terhadap pekerjaan anaknya. 
Ayah merupakan pelindung dalam keluarga, khususnya bagi anak-anaknya baik lakilaki maupun perempuan.

Selanjutnya Ahmad Tafsir dalam Helmawati menjelaskan fungsi orang tua sebagai pendidik dalam keluarga harus dilakukan untuk menciptakan keharmonisan baik di dalam maupun di luar keluarga itu. Fungsi pendidik dalam keluarga meliputi: fungsi biologis, fungsi ekonomi, fungsi kasih sayang, fungsi pendidikan, fungsi perlindungan, fungsi sosialisasi anak, fungsi rekreasi, fungsi status keluarga, dan fungsi agama. (Helmawati, 2014).

Orang tua juga memliki tanggungm,jawab terhadap anaknya selain materi adalah memberikan contoh teladan yang baik bagi anak-anaknya. Tanggung jawab orang tua adalah menanamkan rasa cinta sesama anak, memberikan pendidikan akhlak, menanamkan akidah tauhid, menjauhkan anak dari hal-hal yang tidak baik, menempatkan dalam lingkungan yang baik. (Djamarah, 2014). Senada dengan itu, Purwanto menjelaskan bahwa orang tua megang peranan penting dalam pendidikan anak, meliputi: (a) sebagi tempat pemberi rasa kasih sayang; (b) sebagai pengasuh dan pemelihara; (c) sebagai tempat curhat bagi anak; (d) sebagai pengendali dalam keluarga; (e) sebagai pengarah dalam hubungan pribadi; dan (f) sebagai orang yang mendidik dalam hal emosional. (Purwanto, 1995).

Pada era digital ini orang tua diharapkan mampu menguasai teknologi dalam mengontrol dan mendidik anak. Kemajuan teknologi mempunyai pengaruh yang luar biasa bagi anak. tidak hanya berdampak negatif, tapi juga dapat membantu anak dalam mendapatkan informasi, kreatif, inovatif, cerdas, dan mendampingi anak serta menyaring informasi yang memang baik untuk usianya saat ini namun tidak melarangnya, tapi mengontrol sampai dititik aman. (Khusnul, 2017).

Berdasarkan beberapa konsep di atas maka, keluarga milenial atau disebut juga orang tua milenial berperan penting dalam berbagai sendi kehidupan anak misalnya agama, ekonomi, pendidikan, budaya dan ilmu pengetahuan dan teknologi dan lain sebagainya. Sebuah keluarga akan bermasalah jika fungsi dan perannnya itu tidak dilaksanakan yang pada akhirnya akan muncul tindakan kekerasan fisik dan verbal, hilangnya kasih sayang, tidak adanya penanaman nilai agama dan budi pekerti, tidak adanya interaksi yang meyang menyenangkan, merasa tidak aman dalam keluarga. Sebaliknya apabila orang tua menjalankan fungsi dan perannya dengan baik maka, kehidupan keluarga akan menjadi aman, bahagia dan menyenangkan serta merawat kehidupan keluarga dengan terus-menerus melakukan hal-hal yang positif, konstruktif dan transformatif. Selanjutnya yang tidak kalah penting keluarga milenial tetap terus meningkatkan kemampuan teknologinya, kemampuan literasinya sesuai dengan perkembangan zaman sehingga dapat mendidik anak sesuai zamannya.

\section{Kharakteristik Anak Generasi Digital}

Era digital adalah suatu era dimana semua orang dapat saling berkomunikasi satu sama lain, walau jarak memisahkan, namun semua itu akan terasa dekat dengan adanya perkembangan teknologi dan informasi. Segala informasi sangat mudah dan cepat (real time) didapatkan. Era digital ini dikenal juga sebutan globalisasi. Globalisasi 
merupakan suatu proses integrasi dalam dunia internasional yang disebabkan karena adanya pertukaran dalam segala bidang baik ekonomi, teknologi, budaya dan lain sebagainya. Kemajuan pada era digital ini sangat berpengaruh terhadap semua aspek dalam kehidupan, baik secara positif maupun negatif. Agar orang tua milenial dapat mendidik anak dengan baik di era digital ini, maka orang tua harus mengetahui dan memahami ciri-ciri anak era digital. Ada beberapa ciri anak digital diantaranya aktif dalam menampilkan identitas diri, wawasan yang luas, bebas, Ingin menguasai, sangat bergantung terhadap teknologi, waktunya banyak habis untuk online, Mudah beradaptasi dengan teknologi baru, dan Kemampuannya multitasking artinya mengerjakan beberapa aktivitas secarabersamaan. (Prastiwi, 2021)

Selanjutnya, tidak jauh berbeda dengan pendapat di atas Wafi menjelaskan bahwa ciri-ciri anak era digital (Wafi, 2021) adalah sebagai berikut suka memperlihatkan identitasnya di media sosial seperti facebook, twitter, path, instagram, youtube, dan lain sebagainya, lebih terbuka, suka blak-blakan, menyukai hidup bebas, dan memiliki kemampuan belajar yang cepat seperti mengakses media online. Senada dengan pendapat di atas Andriyani menjelaskan karakteristik generasi era digital sebagai berikut : mempunyai ambisi yang kuat, berpikir praktis, suka yang instan (speed) dan kurang sabar. Anak menyukai kebebasan, percaya diri dan rasa optimis, kritis dalam berpikir. Ingin diakui, dan mahir dalam menggunakan digital dan teknologi informasi. (Andriyani, 2018).

Dari karakateristik di atas jelaslah bahwa mendidik anak di era digital sangat banyak tantangannya jika dibandingkan dengan mendidik anak pada zaman dahulu. Sebabnya, anak-anak sekarang mengalami pertumbuhan dan perkembangan bersamaan dengan kecanggihan teknologi informasi yang sangat mudah diakses dimana saja dan kapan saja. Zaman telah berubah, tentu pola mendidik anakpun juga mengikuti zamannya seperti yang disampaikan oleh Ali bin Abi Thalib bahwa mendidik anak sesuai dengan zamannya anak. Ketika zaman mengalami perubahan, tentu tantangannya juga berubah, seperti tantangan dalam hidup bermasyarakat, dalam bergaul, dalam menuntut ilmu, dan dalam berinteraksi dengan anak, maupun tantangan lainnya. Hal ini menjadi tantangan besar bagi orang tua dalam membangun generasi sesuai zamannya. Maka sebagai peran orang tua milenial yang memiliki sejumlah pengetahuan dan pendidikan sangat dibutuhkan pengalamanpengalamannya, kemampuan literasinya terkait dengan teknologi dan informasi dengan tujuan agar dapat membentengi anak-anak dari pengaruh-pengaruh negatif teknologi dan informasi tersebut.

\section{Problematika Era Digital}

Era digital merupakan suatu era yang ditandai dengan terjadinya perubahanperubahan besar dunia. Manusia saangat mudah mengakses informasi melalui berbagai cara, serta dapat menikmati fasilitas dari teknologi digital dengan bebas. Penggunaan media digital dan teknologi tidak hanya berdampak positif, tetapi juga berimplikasi negatif apabila anak-anak dan remaja menggunakannya secara berlebihan dan lepas kendali. Perkembangan media digital yang meningkat juga memiliki 
pengaruh positif dan negatif yaitu sebagai berikut: pengaruh positif era digital antara lain: a) Informasi cepat dan mudah diakses; b) inovasi diberbagai bidang; c) banyaknya media massa online; d) sumber daya manusia meningkat; e) Munculnya berbagai macam referensi belajar seperti perpustakaan online, media pembelajaran online, diskusi online yang dapat meningkatkan kualitas pendidikan; dan f) Munculnya bisnis online yang sangat mudah didapatkan. (Setiawan, 2017). Sementara itu dampak positif dari era digital lain adalah informasi cepat dan mudah didapatkan, mudah dalam berkomunikasi, mudah mendapatkan informasi, adanya inovasi dalam pembelajaran, dan mudah mendapatkan referensi belajar digital, seperti ebook dan artikel online. (Maulidiyah, 2018). Selain dampak positif, era digital ini juga mempunyai dampak negatif di antaranya adalah prestasi belajar menurun karena penggunaan media digital yang berlebihan, aktivitas fisik anak terbatas, perkembangan keterampilan sosial dan bahasa anak yang terhambat, perkembangan otak tidak maksimal karena stimulasi perkembangan tidak seimbang, masalah kesehatan mata, masalah konsentrasi, masalah tidur, jumlah waktu tidur dan kualitas tidur yang kurang, tidak ada privacy, terjadi kemungkinan hilangnya data pribadi, penculikan anak, cyber bullying, dan pornografi, serta kekerasan.(Zahra, 2016). Selain, itu era digital atau globalisasi juga berpengaruh terhadap budaya lokal di mana generasi sekarang semakin jauh dari adat istiadatnya. (Wahid, 2021).

Dari pendapat di atas dapat dipahami perkembangan media digital mempunyai dampak positif yang sangat membantu individu dalam menjalani kehidupan. Namun telepas dari itu, dampak negatif yang bisa timbul dan perlu diperhatikan oleh orang tua dalam keluarga sebagai orang terdekat bagi anak, agar anak dapat terhindar dari pengaruh negatif. Maka perkembangan era digital harus disikapi dengan serius, menguasai, dan mengendalikan peran teknologi dengan baik agar era digital dapat membawa manfaat bagi kehidupan. Anak-anak dan remaja harus diberikan edukasi tentang manfaat dan dampak negatif yang ada pada era digital ini. Orang tua harus memiliki pengetahuan dan kesadaran yang tinggi agar dapat mengonrol sikap anakanaknya terhadap teknologi dan menggunakannya dengan baik dan benar.

\section{Pola Pengasuhan Orang Tua di Era Digital}

Merujuk dari ciri-ciri generasi digital di atas, maka keluarga milenial atau orang tua milenial sangat diharapkan mendidik anak di era digital dengan memperhatikan tipe-tipe pola asuh yang relevan dengan kehidupan anak saat ini. Orang tua milenial dapat mengimplementasikan pola asuh yang efektif dalam mendidik anak di era digital. Orang tua harus mampu melindungi anak-anak dari ancaman era digital, namun tidak menghalanginya dalam mengambil manfaat dari era digital tersebut. Orang tua milenial dapat menerapkan pola asuh yang bersifat arif, positif, efektif, konstruktif dan transformatif. Pola asuh yang utama adalah effective parenting atau pola asuh yang efektif. (Zaini, 2019).

Ada banyak teori yang menjelaskan tentang pola asuh orang tua terhadap anak dalam keluarga. Secara umum, pola asuh anak dalam keluarga terbagi dalam tiga kategori yaitu pola asuh otoriter, demokrasi, dan permisif. (Kurnia, 2017), hal ini juga 
dijelaskan dalam (Setiawan, 2017) yaitu pola asuh otoriter dengan cara mengasuh dan mendidik anak sepenuhnya dikontrol oleh orang tua, Pola asuh demokrasi, pola asuh ini mengutamakan kepentingan anak, namun tidak sungkan untuk mengontrolnya, dan pola asuh permisif, pola ini memberikan kebebasan kepada anak seoptimal mungkin dan cenderung mendengarkan anak namun terlalu santai.

Setiap orang tua tidak harus menggunakan satu tipe pola asuh, tetapi bisa mengkombinasikan tipe-tipe pola asuh tertentu dalam mendidik dan membentuk anak, sehingga terjadi interaksi yang baik. Apabila interaksi antara orang tua dan anak terjalin dengan baik, hal ini dapat mendukung perkembangan fisik, emosi, sosial, intelektual, dan spiritual berlangsung sejak seorang anak dalam kandungan sampai dewasa. Maka dari itu, pola asuh yang sesungguhnya adalah suatu interaksi yang terjadi antara orang tua dengan dengan anaknya dalam hal pemenuhan kebutuhan fisik (makan, dan minum) dan kebutuhan psikologis (rasa aman, dan kasih sayang), serta mensosialisasikan norma-norma yang berlaku di masyarakat agar anak dapat mengetahui dan hidup selaras, serasi dan seimbang dengan lingkungannya.

Peranan keluarga milenial sangat penting dalam era digital saat ini. Orang tua harus mampu mendampingi dan membimbing anak-anak agar tidak menjadi korban negatif cyber atau era digital. Maka dari itu, orang tua perlu mengimplementasikan strategi berikut ini untuk mendidik dan mendampingi anak supaya tetap bisa menguasai teknologi digital tanpa terpengaruh dampak negatifnya, (Herlina, 2018) yakni:

1. Orang tua membuat komitmen dengan anak tentang penggunaan dan waktu penggunaan fasilitas seperti gadget, smartphone, tab, tablet hingga internet di rumah.

2. Orang tua menjalin kerjasama yang baik dengan pihak sekolah dan masyarakat, agar segala tindakan, prilaku dan sikap anak dapat terkontrol dengan baik.

3. Orang tua harus mendampingi dan memantau aktivitas anak dalam mengakses atau menggunakan media sosial.

4. Orang tua harus mampu menjadi teladan yang baik bagi anak dalam memanfaatkan media sosial dan menjalankan komitmen yang dibuat bersama anak.

Sementara itu, pola asuh dalam Islam adalah bagian integral dari perilaku dan perlakuan orang tua terhadap anaknya sejak kecil mulai dengan cara membesarkan, mendidik, membina, membiasakan, dan membimbing anak secara optimal berdasarkan Al-Qur'an dan Sunnah Nabi Muhammad SAW. Dalam Islam pola pengasuhan anak dibagi menjadi beberapa tahapan perkembangan anak yaitu: (1), pola asuh pada usia 0-6 tahun. Rasulullah Saw telah mencontohkan kepada orangtua agar menyayangi, mengasihi serta memanjakan anak dengan tanpa terbatas. (2), pola asuh pada usia 7-14 tahun. Pada tahap ini kedisiplinan dan tanggungjawab orang tua harus ditanamkan kepada anak. (3), pola asuh usia 15-21 tahun. Pada tahap pola ini, anak sudah memasuki usia aqil baligh sehingga diperlukan teknik dalam menjalin komunikasi dengan anak dan menjadi pendengar yang baik. (4), pola asuh anak usia 
di atas 21 tahun. Pada masa ini kepercayaan dari orang tua dibutuhkan oleh anak. Pada usia ini orang tua hanya dapat memantau dan mengarahkan anak. Nasehat merupakan cara efisien dalam mendidik anak pada tahapan ini. (Anwar, 2020).

Tujuan dari pola asuh ini adalah agar anak memiliki sejumlah kompetensi tertentu yang berguna bagi anak tersebut. Diantara kompetensi yang diharapkan orang tua adalah kompetensi aqidah, kompetensi moral, kompetensi fisik, kompetensi motorik, kompetensi akademik, serta kompetensi sosial emosional. Mengasuh anak itu memerlukan bimbingan dan pembinaan yang terarah dan terprogram secara berkesinambungan, sangat diperlukan oleh orang tua dalam mendidik anaknya. Agar terlaksana dengan baik, maka membimbing anak perlu diperhatikan dalam keluarga adalah dengan memberi contoh teladan, memelihara dan merawat anak agar menjadi penerus dalam keluarga yang memiliki nilai-nilai Islam, serta adanya pembiasaan dengan membiasakan diri dan anak-anak agar cenderung berbuat baik dan meninggalkan keburukan.

\section{Pendidikan Keluarga Islami di Era Digital}

Lingkungan keluarga merupakan tempat di mana anak-anak akan mendapat pendidikan atau pengaruh dari orang tuanya. Keluarga adalah lembaga pendidikan tertua dan orang tua sebagai pendidik kodrati, maka seyogyanya orang tua juga harus mempunyai latar belakang pendidikan yang bagus. Sebab, pendidikan orang tua dalam keluarga akan dapat memberikan sejumlah pengetahuan dan keterampilan, agama dan kepercayaan, nilai-nilai moral, norma sosial serta pandangan hidup yang berguna bagi masa depan anak.

Begitu juga pada era digital ini, orang tua hendaknya lebih intensif lagi memperhatikan si anak sehingga mampu memanfaatkan perkembangan tekhnologi dengan sebaik-baiknya. Beberapa hal yang bisa dilakukan oleh orang tua sebagai pendidik pertama di keluarganya (Hardiani, 2018) adalah sebagai berikut:

1. Memberikan edukasi dan pemahaman kepada anak untuk meninggalkan berbagai perbuatan yang diharamkan seperti merokok, judi, minum khamar, mencuri, mengambil hak orang lain, zhalim, durhaka kepada orang tua dan segenap perbuatan haram lainnya.

2. Mendidik anak agar disiplin terhadap waktu, jangan sampai anak menghabiskan waktunya hanya dengan bermain dengan gedgetnya.

3. Mengajarkan anak agar membiasakan diri memakai pakaian yang sesuai dengan ketetuan syar'i sejak dini. Pakaian laki-laki untuk laki-laki, begitu juga pakaian perempuan untuk anak perempuan. Jangan sampai anak-anak memakai pakaian ala barat, ketat dan tidak menutup aurat. Berkaitan dengan hal ini, Rasulullah SAW bersabda, yang artinya "Barangsiapa yang meniru sebuah kaum, maka dia termasuk mereka." (Shahih, HR. Abu Daud).

4. Memberikan edukasi pada anak untuk tidak mengakses situs-situs pornografi karena bisa menyebabkan anak kecanduan dalam melihatnya.

5. Mengenalkan anak situs-situs yang bermanfaat dalam mencari informasi tentang proses belajar. 
6. Mengajarkan anak agar selalu membiasakan diri melakukan hal yang positif dan bermanfaat.

Selain itu, pendampingan orang tua dalam tumbuh kembang anak merupakan hal yang sangat penting, karena anak-anak era digital kurang sosialisasi, lebih suka sendiri dan lain sebagainya. Agar hal itu tidak terjadi diperlukan pendampingan yang intensif oleh orangtua secara efektif, diantara hal-hal yang dapat orang tua lakukan dalam mendampingi anaknya, (Wafi, 2021) adalah sebagai berikut:

1. Orang tua harus mengupdate pengetahuannya dengan media online seperti website, blog, twitter atau faceboook dan instagram.

2. Mendidik anak agar menggunakan media digital dengan Jelas, buat kesepakatan kapan menggunakannya dan kapan waktu untuk istirahat.

3. Mengatur porsi anak dalam menggunakan media digital dengan kegiatan yang bermanfaat, seperti aktivitas berkesenian, kegiatan luar ruangan, olah raga, membaca interaktif, musik dan gerakan, permainan tradisonal dan sebagainya.

4. Meminjamkan media digital seperti gadget, smart phone, dan komputer sesuai keperluan agar anak bisa belajar dan mengendalikan diri menggunakan media digital.

5. Memilihkan aplikasi yang positif agar berdampak positif pula bagi pertumbuhan dan perkembangan anak.

6. Selalu mendampingi dan berinteraksi dengan anak dalam menggunakan media digital.

7. Orang tua bijaksana dalam dalam menggunakan media digital.

8. Aktifitas dalam dunia maya adalah waktu yang tepat bagi orang tua untuk mempersiapkan anak berkunjung ke dunia maya. Memberikan edukasi tentang konten yang bermanfaat dan menjauhi dari konten negatif.

9. Orang tua harus mengawasi dan memfilter situs-situs website yang sudah dikunjungi anak, dan pastikan jangan sampai anak mengunjung situs-situs pornografi.

Dari penjelasan di atas dapat dipahami bahwa pendidikan keluarga sangat penting, apalagi pada masa digital ini, orang tua harus jeli dalam mempersiapkan anak-anak menghadapi gelombang arus globalisasi agar anak terhindar dari pengarupengaruh negatif. Maka orang tua harus memperbaharui pengetahuan terkait teknologi atau literasi digital agar tidak ketinggalan informasi dengan berpegang teguh kepada al-Qur'an dan Sunnah.

\section{KESIMPULAN}

Di Era digital kemajuan ilmu pengetahuan dan teknologi tidak dapat dihindari. Kemajuan tersebut membawa perubahan besar terhadap tatanan kehidupan. Kemajuan itu dapat dimanfaatkan dari segala kalangan, baik anak-anak maupun orang dewasa. Berbeda dengan zaman dulu, sekarang ini segalanya dilakukan dengan online. Era digital selain berdampak positif, perkembangan teknologi ini juga memiliki dampak negatif. Bagi anak-anak yang masih belum mampu menfilter diri dalam 
pemanfaatan kecanggihan teknologi, sangat dibutuhkan sekali pengawasan dan bimbingan dari orang tua atau dikenal dengan istilah pola asuh. Pola asuh anak dalam keluarga terdiri dari pola asuh otoriter, pola asuh demokratis, pola asuh permisif. Pola asuh yang efektif di era digital adalah pola asuh demokratis. pola asuh ini berupaya menguatkan anak agar bersikap kritis terhadap pengaruh-pengaruh positif dan negatif era digital. Orang tua harus mampu mengontrol dan membimbing anak dalam menggunakan media digital agar tidak menyimpang dari nilai-nilai pendidikan yang sebenarnya. Orang tua yang sayang dan perhatian terhadap anak adalah orang tua yang terlibat dalam seluruh dimensi pembentukan sikap dan karakter anak. Artinya, orang tua yang tidak hanya piawai dan paham dengan berbagai macam hal dan istilah teknis dari perangkat dan media digital yang akan dibeli atau telah digunakan oleh anak. Akan tetapi, selama anak masih bergantung kepada orang tua, maka seyogyanya orang tua mesti mengetahui dari media online tersebut dan pandai menggunakannya. Orang tua yang bijaksana dan bertanggungjawab tidak boleh menyerahkan sepenuhnya kepada anak dalam menggunakan media digital. Orang tua harus mampu berkomunikasi dengan baik menjalin kerjasama yang baik pihak sekolah dan masyarakat agar anak terawasi dengan baik.

Selanjutnya dalam penggunaan media digital harus ada komitmen antara orang tua dan anak dalam menggunakan media digital, baik waktu, apa saja yang boleh diakses dan orang tua harus mengupdate informasinya agar tidak ketianggalan. Kesuksesan seorang anak dalam proses pendidikan sangat ditentukan dari proses pendidikan dalam keluarga. Keluarga sebagai lembaga pendidikan merupakan basis pertama dan utama dalam membentuk dan membina anak sebagai generasi yang siap dan kristis dalam menghadapi pengaruh era digital zaman ini, bukan larut di dalam tetapi mampu memainkan peranannya untuk masa yang akan datang. maka seyogyanya orang tua juga harus mempunyai latar belakang pendidikan yang bagus. Sebab, pendidikan orang tua dalam keluarga akan dapat memberikan sejumlah pengetahuan dan keterampilan, agama dan kepercayaan, nilai-nilai moral, norma sosial serta pandangan hidup yang berguna bagi masa depan anak.

\section{DAFTAR PUSTAKA}

Ainiyah, Nur. (2017). Membangun Penguatan Budaya Literasi Media dan Informasi dalam Dunia Pendidikan. JPII Vol. 2, No.1 Oktober 2017.

Andriyani, Isnanita Noviya. (2018). Pendidikan Anak dalam Keluarga Di Era Digital. FIKROTUNA: Jurnal Pendidikan dan Manajemen Islam Volume 7, Nomor 1, Juli 2018; $p$-ISSN 2442-2401; e-ISSN 2477-5622.

Daradjat, Zakiah. (1973). Peranan Agama dalam Kesehatan Mental. Jakarta: Gunung Agung.

Departemen Agama. (2009). Al-Qur'an dan Terjemahnya, Bandung: CV. Diponegoro

Djamarah, Syaiful Bahri. (2014). Pola Asuh Orang Tua dan Komunikasi dalam Keluarga, Jakarta: Rineka Cipta

Hardiani \& Kiki Mariah. (2018). Urgensi Pendidikan Keluarga Islami Pada Era Digital, 
Batu Sangkar: 3rd International Conference on Education 2018 Teachers in the Digital Age, 137-144

Hasbullah. (2003). Dasar-Dasar Ilmu Pendidikan, jakarta: PT raaja grafindo persada

Helmawati. (2014). Pendidikan Keluarga Teoritis Dan Praktis. Bandjung: PT. Remaja Rosdakarya.

Herlina, Dyna, Benni Setiawan dan Gilang Jiwana. (2018). Digital Parenting : Mendidik Anak di Era Digital. Yogyakarta : Samudra Biru.

Iswan dan Herwina. (2018). Penguatan Pendidikan Karakter Perspektif Islam dalam Era Millenial IR. 4.0. Prosiding Seminar Nasional Pendidikan Era Revolusi "Membangun Sinergitas dalam Penguatan Pendidikan Karakter pada Era IR 4.0" Universitas Muhammadiyah Jakarta, Indonesia, 24 Maret 2018 ISSN : 2621-6477.

Juwita, Dwi Ratna. (2018). Pendidikan Akhlak Anak Usia Dini di Era Millenial. At-Tajdid: Jurnal Ilmu Tarbiyah, Vol. 7, No.2, Juli 2018.

Khusnul Laely, et.al. (2017), "Parenting Pengasuhan di Era Digital dalam Rangka Mendukung Terwujudnya PKBM (Pusat BelajarMasyarakat) di Daerah Miskin", jurnal: The 6Universit Research Colloquium Universitas Muhammadiyah Magelang, h.4-5

Kurnia, Novi, Engelbertus Wendratama, Wisnu Martha Adiputra, Intania Poerwaningtias. (2017). Literasi Digital Keluarga, Teori dan Praktik Pendampingan Orangtua terhadap Anak dalam Berinternet. Yogyakarta : Program Studi Magister Ilmu Komunikasi UGM.

Prastiwi,Mahar.

https://edukasi.kompas.com/read/2021/04/27/160900471/psikolog-ugm-orangtua-wajib-tahu-8-karakteristik-generasi-digital?page=all.

Purwanto, Ngalim, (1995). Ilmu Pendidikan Praktis dan Teoretis. Bandung: Remaja Rosda Karya.

Rahmat, Stephanus Turibius. (2018). Pola Asuh Yang Efektif Untuk Mendidik Anak Di Era Digital. Jurnal Pendidikan dan Kebudayaan Missio, Volume 10, Nomor 2, Juni 2018, hlm. 137-273.

Rahmawati, Novi R. (2019). Pola Pengasuhan Orangtua Milenial, Proceeding of International Conference on Islamic Education: Challenges in Technology and Literacy Faculty of Education and Teacher Training, Universitas Islam Negeri Maulana Malik Ibrahim Malang, Vol. 4

Riri Zahra. (2016). http://www.mungilmu.com/single-post/2016/10/22/TantanganMendidik-Anak-di-Era-Digital

Setiawan, S. (2017). Pengaruh Bentuk Pola Asuh Orang Tua Dan Regulasi Diri Terhadap Disiplin Siswa (SMP 17 Agustus 1945 Samarinda). Ejournal.Psikologi.IsipUnmul.Ac.Id, 5(2), 310-319.

Sari, M., \& Asmendri, A. (2020). Penelitian Kepustakaan (Library Research) dalam Penelitian Pendidikan IPA. Natural Science: Jurnal Penelitian Bidang IPA dan Pendidikan IPA, 6(1), 41-53

Setiawan, Wawan. (2017). Era Digital dan Tantangannya. Universitas Putra Indonesia.

Setyawati, N. (2020). Implementasisanksi pidana bagi masyarakat yang beraktivitas di luar 
Journal Continuous Education

Volume 2, Issue 2, July 2021

Page 1-13

rumah saat terjadinya pandemi Covid19. Jurnal Education And Evelopment, 8(2), 135135.

Tritularsih, Y \& Sutopo. W, (2017). Peran Keilmuan Teknik Industri Dalam Perkembangan Rantai Pasokan Menuju Era Industri 4.0. Seminar Dan Konferensi NasionalIDEC, 507517.

Umar, M. (2015). Peranan Orang Tua Dalam Peningkatan Prestasi Belajar Anak. Jurnal Edukasi: Jurnal Bimbingan Konseling, 9(1), 20-28.

Wafi, Hibatul. (2021). http://pai.unida.gontor.ac.id/mendidik-anak-di-era-digital/

Wahid, Amirul RWZ dan Bagus Prayogi, (2021), Preservasi Budaya Osing Melalui Internalisasi Budaya Berbasis Sekolah Adat Sebagai Bentuk Pengabdian Masyarakat, Journal of Education and Teaching Learning (JETL) Volume 3, No 2, Mei 2021, 44-59

Wahono, Heru Totok Tri dan Yulia Effrisanti. (2018). Literasi Digital di Era Millenial. Prosiding Seminar Nasional Hasil Penelitian Pendidikan dan Pembelajaran STKIP PGRI Jombang, Jawa Timur, Indonesia,7April 2018 Volume 4 No. 1 Tahun 2018, ISSN 2443-1923.

Wicaksono, dkk. (2019). Demokrasi Damai Era Digital. Jakarta : Siberkreasi.

Winerda, Indah dan Intan Rawit Sapanti. (2019). Literasi Digital Bagi Millenial Moms.

Zaini, Muhammad dan Soenarto. 2019. Persepsi Orangtua Terhadap Hadirnya Era Teknologi Digital di Kalangan Anak Usian Dini. Jurnal Obsesi : Jurnal Pendidikan Anak Usia Dini, Vol. 3, No. 12019 (224-233).

Zed, Mestika. (2008). Penelitian Kepustakaan, Jakarta: Yayasan Obor Indonesia 